\title{
Management and implementation models on seed production of hybrid maize based on labor intensive
}

\author{
Susilawati ${ }^{*}$, and Twenty Liana $^{2}$ \\ ${ }^{1}$ Assesment Institute of Agricultural Technology for Central Kalimantan \\ ${ }^{2}$ Center for Seed Supervision and Certification, Central Kalimantan
}

\begin{abstract}
The production of hybrid maize seeds at the field level can be done by farmers, with the main constraints being limited human resources and capital. For economic recovery during Covid-19 in 2020, the Gunung Mas district government launched a "Cash labor-intensive program" to the community. One of the groups, Sei Kurun farmer group, used it for an innovative and productive hybrid maize seed business. The goal is to grow group as breeder of hybrid maize seed, and empower farmers in a productive and sustainable manner. The method applied is in the form of cooperation and assistance between farmer groups, the Agriculture Service as a partner and prospective buyer of the seeds produced, and AIAT of Central Kalimantan as a companion for the application of technology. The results showed that cash funds for $\mathrm{JH} 37$ hybrid maize seeds can be implemented on 3 hectares, and have produced 1.5 tons of $\mathrm{F} 1$ hybrid seeds, which are then sold through the District Agriculture Office program. with a profit of IDR $35,440,000$. This farming is feasible with an R/C of 3.08, and becomes a profitable and sustainable farm, as well as a choice of model for using labor-intensive funds.
\end{abstract}

\section{Introduction}

Maize is one of the main commodities that are widely grown in Indonesia, and can be grown in almost all agro-ecosystems. A part from being a food ingredient, maize is also used as an animal feed ingredient, a raw material for the gluten industry, and a sweetener [1]. The most widely grown types are hybrids, with the number increasing every year. The use of hybrid maize seeds is an option to replace composite maize and local maize which have low productivity. The productivity of hybrid maize ranges from 10-13 t/ha, higher than composite or local varieties, which are generally less than $3 \mathrm{t} / \mathrm{ha}[2]$.

The increase in the planted area of maize every year must be followed by the availability of sufficient seeds. Data for 2020 shows that the maize planted area in Indonesia reaches 5.5 million hectares, an increase from the previous year. The amount of seed needed is around 220,000 tons as mentioned by Indonesian Statistics. Production of hybrid maize seeds is not only provided by large-scale seed producers, but also by small-

* Corresponding author: susi_basith@yahoo.com 
scale seed producers, namely breeders or groups of breeders. Some of the advantages of seeds that can be produced include 1) high yields, 2) resistance to pests and diseases, thus supporting cropping patterns and integrated pest control programs, 3) early maturity, to increase cropping index, and 4) superior yield quality. so that it is in accordance with consumer tastes [3, 4].. By understanding this, the role of breeders at the field level becomes very important, especially to provide quality seeds at the field level in accordance with six precise principles, namely the right variety, quality, quantity, time, location and price. Constraints faced in the implementation of captivity at the level of breeders or breeder groups include human resources, infrastructure and facilities, and very limited capital 5]. Technical Instructions for Hybrid Maize Seed Production Technology.

The cash-for-work program was launched by the Gunung Mas government, Central Kalimantan, in the context of economic recovery during Covid-19, is one of the breakthroughs used by farmer groups to become hybrid maize seed breeders. The cash assistance received by the community can be used as capital and used by farmer groups to carry out innovative cultivation of hybrid maize seeds. The purpose of the activity is to empower farmers in a productive and sustainable manner, to grow a group of breeders who are able to produce hybrid maize seeds, to provide income as well as to support the maize farming development program.

\section{Materials and methods}

\subsection{Time and place}

The activity was carried out in the Sei Kurun farmer group, in Kurun Seberang sub district, Gunung Mas Regency of Central Kalimantan, from November 2020 to April 2021. The activity began with making group agreements to use cash labor-intensive assistance funds for innovative hybrid maize seed businesses, and e AIAT of Central Kalimantan as a companion innovation, preparation of group business plans, conducting technical guidance before starting activities, and mentoring during implementation in the field.

\subsection{Group business plans and technology packages}

The implementation of an innovative hybrid maize seed business begins with preparing a group business plan or preparing a technology package that was depent on the available funds. The agreed activity was in the form of JH 37 hybrid maize seeds purchased from the Cereal Crops Research Institute. The breeding area is 3 ha and involves 6 prospective farmers as breeder. The technology package prepared as a group business plan is adjusted to the availability of the group budget obtained from cash labor-intensive funds (Table 1).

Table 1. Technology components for seed production JH 37 hybrid maize per hectare

\begin{tabular}{|c|l|c|}
\hline No & \multicolumn{1}{|c|}{ Technology components } & Total \\
\hline 1 & Male parent seed $(\mathrm{kg})$ & 5 \\
\hline 2 & Female parent seed $(\mathrm{kg})$ & 15 \\
\hline 3 & Manure $(\mathrm{kg})$ & 2.000 \\
\hline 4 & Herbicide $(\mathrm{L})$ & 4 \\
\hline 5 & Dolomit $(\mathrm{kg})$ & 500 \\
\hline 6 & Urea $(\mathrm{kg})$ & 200 \\
\hline 7 & NPK $(\mathrm{kg})$ & 300 \\
\hline 8 & KCL $(\mathrm{kg})$ & 100 \\
\hline 9 & Organic fertilizer & 10 \\
\hline
\end{tabular}




\subsection{Technical guidance for farmer group as breeders}

Technical guidance is carried out by a team from Central Kalimantan AIAT, and is followed by all prospective breeders together with Field Agricultural Extension Worker (PPL). The material presented is technology of hybrid maize seed, with discussion methods and field practice. Some of the main technicalities in seed technology were presented, such as tillage, which in this activity was carried out perfectly. Setting the spacing of $70 \times 25 \mathrm{~cm}$, fertilizing according to the recommendations that have been prepared [5]. Roguing, detachment and techniques for harvesting and processing crops. In the implementation of this technical guidance, do not forget to distribute initial and final questionnaires to determine the knowledge and understanding of prospective breeders before and after the implementation of technical guidance

In terms of readiness to carry out captive breeding in a sustainable manner, prospective breeders are committed to carrying out seeding activities, and are willing to follow all instructions and are able to cultivate maize seeds properly. After the plants produce and produce seeds, the breeding group also wants to develop more widely and sustainably.

\subsection{Implementation and process of data collection}

The implementation of hybrid maize breeding conducted by the Sei Kurun farmer group is to produce hybrid maize seeds of the $\mathrm{JH} 37$ (F1) variety, with parent seeds from the Cereala Crops Research Institute. Planting began in November 2020, by planting male seeds (CLY231), three days later the female seeds (MAL03) were planted. The ratio used is 1: 3 , namely 1 row of male parent, 3 rows of female parent, so that for 1 ha of land it takes $5 \mathrm{~kg}$ male parent and $15 \mathrm{~kg}$ female parent. To produce quality seeds that are kept pure, inspection of plants that deviate or off type is carried out during roguing/selection. Roguing was carried out 2 times, namely at the vegetative growth stage (32-35 Day After Planting/DAP) and generative (45-52 DAP). Detachment or removal of male flowers carried out at the time the plants are flowering or at the age of 45-56 HST or before the female parent plants open (anthesis), as well as harvesting and processing harvesting techniques.

The data collected in this activity included: (1) growth and production data, namely plant height at harvest, weight of cob and without stalks, number of rows of seeds/cob, weight of 1000 seeds, yield of dry shells/cobs, and yield per hectare; which passes to become seeds or not. All data were analyzed qualitatively and quantitatively from each implementing farmer. (2) Other data affecting seed production, such as pests and plant diseases, as well as other disturbances that affect plant growth and development. (3) An analysis of income and farming from the application of seed technology innovation is carried out [6], analysis of the break-even point of production (TIP) and price break-even point $(\mathrm{TIH})$, so that the feasibility and benefits of this farming are known. Furthermore, this model can be recommended and carried out on an ongoing basis in a labor-intensive program.

\section{Results and discussion}

\subsection{The level of knowledge and understanding of farmers in the production of hybrid maize seeds}

The results of the questionnaire showed that the level of understanding of farmers about seeds or how to produce hybrid maize seeds, increased compared to before following the 
technical guidance. Before technical guidance about $96 \%$ of farmers did not understand how to produce hybrid maize seeds, as many as $4 \%$ knew how to produce hybrid maize seeds. As many as $100 \%$ of farmers have never done. Farmers who know how to make hybrid maize seeds get initial information from the internet, but do not know how to get male and female parent. As many as $43 \%$ of officers already know how to plant and handle post-harvest hybrid maize to sell it, but only a part of the technical training participants understand the provisions in producing hybrid maize seeds. All farmers and PPLs do not understand the terms and how to carry out the cultivation process in producing hybrid maize.

After training or technical guidance, farmers understand several things in the process of making hybrid maize seeds. As many as $99 \%$ of farmers and officers understand the existence of male and female parent, and how to plant male parent earlier than female parent $[7,8]$. All growers know why male parent should be planted early and when to dispose of male flowers. Several terms in hybrid maize seed have been understood. In addition, maize cultivation techniques such as how to fertilize, fertilizing time, the dose that must be applied and maintenance are understood by farmers $100 \%$ after the implementation of technical guidance. Many farmers or around $87 \%$ know very well how to control pests and diseases on maize plants chemically, only about $13 \%$ are aware of other methods such as using vegetable or organic materials and physical control.

The results of this questionnaire also show that the implementation of activities in the field can be carried out well. Assistance at the field level shows that some innovations are working and can be well received by farmers. The use of superior seeds from IAARD is acceptable, although so far it has not been available in the market. In the case of fertilizer recommendations, namely $200 \mathrm{~kg} / \mathrm{ha}$ urea and $300 \mathrm{~kg} / \mathrm{ha} \mathrm{NPK}$, farmers can only meet with labor-intensive funds of $100 \mathrm{~kg} / \mathrm{ha}$ urea and $200 \mathrm{~kg} / \mathrm{ha}$ NPK. The enthusiasm and great desire of farmers encourage farmers to be able to meet the needs of these recommendations from their respective funds, so that all technology components can be fulfilled by prospective breeder farmers.

\subsection{Application of hybrid maize seed cultivation technology package}

\subsubsection{Observations at the vegetative phase}

The results of the application of the JH 37 hybrid maize seed technology package which was carried out intensively by a beginner breeder group showed that male and female plants grew well and evenly until the age of 15 days after planting (DAP). Especially for female parent, plant height at the age of 15 DAP ranged from 25.67 to $26.42 \mathrm{~cm}$. However, at 30 days after planting, the growth of the female parent plants looked uneven, even tended to be abnormal or slow, with a plant height of $31.43-45.42 \mathrm{~cm}$ (Table 2). One of the causes is thought to be due to the low nutrient content of the soil, which is dominated by sand. The results of soil analysis also showed that macro and micro parameters such as $\mathrm{N}, \mathrm{P}, \mathrm{Na}, \mathrm{Mg}$, Ca were low (attached). 
Table 2. Average plant height of female parents at the age of 15,30 and 45 DAP

\begin{tabular}{|c|c|c|c|}
\hline \multirow{2}{*}{ Farmers } & \multicolumn{3}{|c|}{ Plant height (cm) } \\
\cline { 2 - 4 } & 15 DAP & 30 DAP & 45 DAP \\
\hline A & 25.67 & 31.66 & 64.33 \\
\hline B & 26.13 & 45.32 & 66.67 \\
\hline C & 26.42 & 32.54 & 56.00 \\
\hline D & 25.98 & 35.63 & 61.33 \\
\hline E & 26.33 & 31.43 & 61.33 \\
\hline F & 26.18 & 40.38 & 58.67 \\
\hline
\end{tabular}

The addition of a single manure as much as $1 \mathrm{t} / \mathrm{ha}$ was able to increase fertility and restore plant growth to normal, as seen in observations at 45 DAP (Table 2). This application also proves that the dose of manure given as much as $1 \mathrm{t} / \mathrm{ha}$ at the initial stage is not enough, so that the optimal amount of manure applied to sandy soil in this hybrid maize seed farming reaches 2 tons/ha. As is well known, manure is fertilizer that comes from cattle pens, either in the form of solid manure (feces) mixed with food residue and urine, which contains a number of nutrients [9], [10], stated that cow manure solid with a moisture content of $85 \%$ containing $0.40 \% \mathrm{~N} ; 0.20 \%$, P2O5 and $0.1 \% \mathrm{~K} 2 \mathrm{O}$ and the liquid with a water content of $95 \%$ contains $1 \% \mathrm{~N} ; 0.2 \%$, P2O5 and $1.35 \% \mathrm{~K} 2 \mathrm{O}$. Likewise with chicken manure which can improve the physical, chemical and biological properties of the soil, increase the availability of soil nutrients, bind water and can reduce the toxic nature of $\mathrm{Al}$ contained in ultisol soil. N, P, K fertilizers can provide nutrients quickly so that the growth and production of maize increases [11]. Chemically, manure is able to add nutrients, especially NPK and increase CEC and biologically it can increase the activity of soil microorganisms. One type of organic fertilizer that is often used as an addition to soil organic matter is manure.

\subsubsection{Observation of the production components on female parent}

The results of observations on several components of growth and production in female parent plants showed that the flowering and physiological maturity of plants did not differ in all farmers. The weight of cobs ranged from $123.23-150.53 \mathrm{~g}$, with the lowest numbers occurring in farmers' plants A and C, with of 123.97 grams and 123.9 grams, respectively. Likewise, the weight of the cob without the cob is 116.90 grams and 117.18 grams, respectively. Even though the female parent planted on farmers' A and C's fields, both cob weights and unhulled cobs were equally low, but the plants in farmer A produced higher seeds than farmer $\mathrm{C}$, which was $9,731.53 \mathrm{~g}$. After observing, it turned out that the grain produced by farmer A was larger than farmer C, whose grain weight at harvest was $8,518.37 \mathrm{~kg}$ (Table 3). 
Table 3. Growth and production components of the JH 37 hybrid F1 at Gunung Mas, 2021

\begin{tabular}{|l|c|c|c|c|c|c|}
\hline \multirow{2}{*}{ Characters } & \multicolumn{6}{c|}{ Farmers } \\
\cline { 2 - 7 } & A & B & C & D & E & F \\
\hline Flowering age (days) & 52.0 & 52.0 & 52.0 & 52.0 & 52.0 & 52.0 \\
\hline $\begin{array}{l}\text { Physiological maturity age } \\
\text { (days) }\end{array}$ & 92.0 & 92.0 & 92.0 & 92.0 & 92.0 & 92.0 \\
\hline Cob location height (cm) & 93.8 & 98.2 & 91.8 & 91.6 & 100.0 & 105.0 \\
\hline Cob weight (g) & 124.0 & 140.4 & 123.2 & 131.5 & 143.2 & 150.5 \\
\hline $\begin{array}{l}\text { Cob weight without hulls } \\
\text { (g) }\end{array}$ & 116.9 & 132.3 & 117.2 & 124.0 & 129.5 & 138.9 \\
\hline $\begin{array}{l}\text { Number seeds in rows per } \\
\text { cob }\end{array}$ & 16.4 & 17.2 & 15.6 & 15.6 & 17.6 & 18.0 \\
\hline Weight 1000 seeds (g) & 301.0 & 275.8 & 282.0 & 295.8 & 296.2 & 317.0 \\
\hline Cob length (mm) & 111.0 & 115.3 & 116.1 & 119.7 & 121.7 & 130.4 \\
\hline Cob diameter (mm) & 40.8 & 42.4 & 41.0 & 42.4 & 42.1 & 41.9 \\
\hline $\begin{array}{l}\text { Seed moisture content at } \\
\text { harvest }\end{array}$ & 36.4 & 37.4 & 36.9 & 37.2 & 37.5 & 37.0 \\
\hline Seed yield (kg) & $9.731,5$ & $10.553,9$ & $8.518,4$ & 9078,9 & $10.425,6$ & $13.789,5$ \\
\hline
\end{tabular}

If it is seen from the amount of inorganic fertilizer given and combined with manure, it can be seen that the planting of farmer $\mathrm{F}$ can give the highest seed yield of $13.79 \mathrm{~g}$ and the lowest is found in farmer $\mathrm{C}$ of $8.518 \mathrm{~g}$. According to [12], the provision of organic matter in addition to playing a role in improving the physical properties of the soil, is also able to supply nutrients, especially mineral nutrients and amino acids for plants, so as to increase growth, restore soil balance and retain nutrients longer to support optimal plant growth. In this observation, farmer F was able to obtain better results than other farmers. Seed yields from female plants, which are part of the process of producing F1 hybrid seeds, reached $13.79 \mathrm{t} / \mathrm{ha}$ with a moisture content of $36.44-37.48 \%$ at harvest. Furthermore, seed processing is carried out to produce $\mathrm{F} 1$ hybrid seeds through cob selection and drying to get a moisture content of $11-12 \%$, as one of the seed requirements.

\subsection{Production of F1 hybrid maize seeds $\mathrm{JH} 37$ and farming analysis}

From this whole series of labor-intensive seedling cultivation, 3.47 tons/ha of dry shelled F1 hybrid seeds were obtained, which were then sent to BPSB for testing and certification. In this process only about 1.5 tons of hybrid seeds passed the test and could be certified as seeds. Some of the seeds did not pass during testing, among others, due to the high moisture content of the prospective seeds, due to high rainfall at harvest, and the unavailability of dryers or farmers still relying on drying in the sun. Frequent rainy days also delay harvest time so that the plants are late for harvesting. Even though it was explained that late harvesting resulted in a decrease in quality and an increase in yield loss, because damaged grains would increase as a result of the influence of unfavorable weather and infection with pests and diseases in the field. Kelobot does not fully protect corn kernels $[13,14,15]$.

Farming analysis of the results of labor-intensive hybrid corn seed cultivation shows that all production input costs reach Rp. 9,660,000 or 53\% and are higher than labor costs which reach Rp. 7,400,000 or 47\%). From this farming, a profit of IDR 35,440,000 was obtained with an $\mathrm{R} / \mathrm{C}$ value of 3.08 . This shows that this seed farming is very feasible to do. This is because the seeds produced have been absorbed to carry out the corn development program and are sold at a price of Rp. 35,000 kg-1 (Table 4). 
Likewise, the analysis based on the Production Break-even Point (TIP) of JH 37 Hybrid maize seed technology conducted in Gunung Mas district using labor-intensive funds was $487 \mathrm{~kg} / \mathrm{ha}$, this shows that the production break-even point limit is $487 \mathrm{~kg} / \mathrm{ha}$. If the production is less than $471 \mathrm{~kg} / \mathrm{ha}$, the JH 37 hybrid corn seed propagation will suffer losses and if it is greater than $471 \mathrm{~kg} / \mathrm{ha}$, the $\mathrm{JH} 37$ hybrid corn seed propagation farm will be profitable (Table 4).

Table 4. Farming analysis of JH 37 hibrid maize seeds in Gunung Mas Regency, 2021

\begin{tabular}{|c|c|c|c|c|}
\hline Description & Unit & Total & $\begin{array}{l}\text { Unit Price } \\
\text { (Rp) }\end{array}$ & Cost (Rp) \\
\hline \multicolumn{5}{|l|}{ Production facilities } \\
\hline Male parent seed & $\mathrm{kg}$ & 5 & 145,000 & 725,000 \\
\hline Female parent seed & $\mathrm{kg}$ & 15 & 155,000 & $2,325,000$ \\
\hline Herbicide & $\mathrm{L}$ & 4 & 60,000 & 240,000 \\
\hline Dolomite & $\mathrm{kg}$ & 500 & 1,500 & 750,000 \\
\hline Urea & $\mathrm{kg}$ & 200 & 2,250 & 450,000 \\
\hline NPK & $\mathrm{kg}$ & 300 & 2,300 & 690,000 \\
\hline KCL & $\mathrm{kg}$ & 100 & 8,000 & 800,000 \\
\hline Manure & Sack & 50 & 15,000 & 750,000 \\
\hline Harvest sack & Lembar & 100 & 2,000 & 200,000 \\
\hline Tarpaulin & Unit & 2 & 165,000 & 330,000 \\
\hline Packaging pouch & Unit & 300 & 5,000 & $1,500,000$ \\
\hline \multirow[t]{2}{*}{ Organic fertilizer } & $\mathrm{L}$ & 10 & 90,000 & 900,000 \\
\hline & & & & $9,660,000$ \\
\hline \multicolumn{5}{|l|}{ Labor } \\
\hline Cultivation & PD & 8 & 100,000 & 800,000 \\
\hline Plant male parent & PD & 4 & 100,000 & 400,000 \\
\hline Plant female parent & PD & 6 & 100,000 & 600,000 \\
\hline Lime and manure & PD & 4 & 100,000 & 400,000 \\
\hline Fertilizer I & PD & 6 & 100,000 & 600,000 \\
\hline Fertilizer II & PD & 2 & 100,000 & 200,000 \\
\hline $\begin{array}{l}\text { Maintenance (seasoning, } \\
\text { POPT) }\end{array}$ & PD & 12 & 100,000 & $1,200,000$ \\
\hline Rouquing & PD & 2 & 100,000 & 200,000 \\
\hline detachment & PD & 12 & 100,000 & $1,200,000$ \\
\hline Harvest & PD & 12 & 100,000 & $1,200,000$ \\
\hline \multirow[t]{2}{*}{ Processing results } & PD & 6 & 100,000 & 600,000 \\
\hline & & & & $7,400,000$ \\
\hline \multicolumn{5}{|l|}{ Total production cost } \\
\hline Labeled Seed Production & $\mathrm{kg}$ & 1,500 & & $\mathbf{1 7 , 0 6 0 , 0 0 0}$ \\
\hline $\begin{array}{l}\text { Selling Price of Seeds to the } \\
\text { Office }\end{array}$ & $\mathrm{Rp}$ & 35,000 & & \\
\hline Reception & $\mathrm{Rp}$ & & $52,500,000$ & \\
\hline Advantage & $\mathrm{Rp}$ & & $35,440,000$ & \\
\hline $\mathrm{R} / \mathrm{C}$ & & 3.08 & & \\
\hline $\mathrm{B} / \mathrm{C}$ & & 2.08 & & \\
\hline TIP & $\mathrm{kg} / \mathrm{ha}$ & 487 & & \\
\hline TIH & $\mathrm{Rp}$ & 11,373 & & \\
\hline
\end{tabular}




\section{Conclusion}

The use of cash labor-intensive funds for producing seed of hybrid maize has proven to be able to grow a productive farmer group as a breeder, and it is feasible to be developed towards sustainable farming. The hybrid maize seed business and assistance at the field level can be recommended as a model for utilizing cash assistance programs to the community that can improve the economy recovery.

Acknowledgement. We thank to the Head Goverment and Agriculture Services of the Gunung Mas Regency who have trusted to Central Kalimantan AIAT for design and assist the implementation of the cash-intensive program in Gunung Mas Regency.

\section{References}

1. Distanak, 2017. The Implementation report for Central Kalimantan Food Crops Production Development Activities in 2017 (Laporan Pelaksanaan Kegiatan Pengembangan Produksi Tanaman Pangan Kalimantan Tengah Tahun 2017). Department of Agriculture and Livestock of Central Kalimantan (Dinas Pertanian dan Peternakan Provinsi Kalimantan Tengah) (2017).

2. S. B. Priyanto, R. Efendi, M Azrai. Journal of Food Crops Agricultural Research (J Penelitian Pertanian Tanaman Pangan). 5, 1 (2021)

3. Nugraha, U.S. Development of seed industry and institutions (Perkembangan industri dan kelembagaan perbenihan) (2013).

4. Malian AH. 2000. Analysis of the economics of farming and the financial feasibility of technology on an assessment scale. Paper presented in the Financial and Economic Analysis training for System Development and Regional Agribusiness Farming. Bogor (Analisis ekonomi usahatani dan kelayakan finansial teknologi pada skala pengkajian. Makalah disajikan dalam pelatihan Analisis Finansial dan Ekonomi bagi Pengembangan Sistem dan Usahatani Agribisnis Wilayah. Bogor, 29 November- 9 Desember) (2000)

5. Azrai et al. Technical Instructions for Hybrid Maize Seed Production Technology (Petunjuk Teknis Teknologi Produksi Benih Jagung Hibrida). (2018)

6. Soekartawi. Theory of Production Economics with the subject of Cobb Douglas Analisis Analysis (Teori Ekonomi Produksi dengan Pokok Bahasan Analisis CobbDouglas). Jakarta : PT Raja Grafindo Persada. 250 ha (2003).

7. Heinz, R., L.P. Ribeiro, M.C. Gonçalves, L.L. Bhering and P.E. Teodoro. Acta Scientiarum - Agronomy 41(1): 1-7 (2019)

8. Abubakar, A.W., A. A. Manga, A. Y. Kamara, and A. I. Tofa. Advances in Agriculture: 1-6. (2019).

9. Heddy S dan Guritno B. 2013. "Study of Addition of Goat Manure and Different Plant Density on Growth and Yield of Sweet Corn Plants" (Kajian Penambahan Pupuk Kandang Kambing Dan Kerapatan Tanaman Yang Berbeda Pada Pertumbuhan Dan Hasil Tanaman Jagung Manis (Zea mays Saccharata Sturt)" Jurusan Budidaya Pertanian, Fakultas Pertanian, Universitas Brawijaya. Tisdale dan Nelson (1985)

10. Tisdale and Nelson. Soil Fertility and Fertilizers. Fourth Edition. Mac millan Publishing Company, New York. 754 p (1985)

11. Widowati, L.R., Sri Widati, U. Jaenudin, dan W. Hartatik. Effect of Organic Fertilizer Compost Enriched with Mineral and Biological Fertilizers on Soil Properties, Nutrient Uptake and Organic Vegetable Production (Pengaruh Kompos Pupuk Organik yang Diperkaya denan Bahan Mineral dan Pupuk Hayati terhadap Sifatsifat Tanah, Serapan Hara dan Produksi Sayuran Organik). Balai Penelitian Tanah Bogor (2005). 
12. Fattah. J Agrotechnology (Jurnal Online Agroekoteknologi). 3(1) : 238 - 245 Desember 2015.

13. Nugraha, U.S., Subandi dan A. Hasanuddin,. Development of corn seed industry and cultivation technology. (Perkembangan teknologi budidaya dan industri benih jagung. Dalam: Kasriyono et al. (Eds) Ekonomi Jagung Indonesia. Badan Penelitian dan Pengembangan Pertanian, Deptan, hal: 37-72 (2002).

14. Syafruddin, Faesal, dan M. Akil. Nutrient Management in Corn Plants. In Corn: Production and Development Techniques. Research Institute (Pengelolaan Hara pada Tanaman Jagung. (Dalam Jagung : Teknik Produksi dan Pengembangan. Balai Penelitian Tanaman Serealia. Maros. Hal 205-218 (2016).

15. Emede, T O, and J E Alika. Best Journal 12(3): 83-97 (2015) 